\title{
Zmiany konstrukcji podatku dochodowego od osób fizycznych a pozapłacowe koszty pracy w Polsce
}

New Personal Income Tax regulations versus non-wage employment costs in Poland

\section{Wprowadzenie}

Obciążenia fiskalne nakładane na wynagrodzenia są uznawane za jedne z najbardziej szkodliwych z punktu widzenia wzrostu gospodarczego. Eksperci OECD i Komisji Europejskiej od dawna postulują przesunięcie ciężaru podatkowego w kierunku danin wywołujących mniejsze zniekształcenia w procesie alokacji zasobów (OECD, 2010). Panuje powszechna opinia, że opodatkowanie pracy w Polsce jest szczególnie wysokie (OECD, 2010), zaś w badaniach ankietowych przeprowadzanych wśród przedsiębiorców czynnik ten od lat jest wskazywany jako główna bariera rozwoju aktywności gospodarczej (BCC i Instytut GFK, 2011; Wyrzykowski, 2013, s. 153-155).

Polskich regulacji dotyczących opodatkowania i oskładkowania dochodów z pracy od wielu lat nie poddawano zmianom. Dopiero z początkiem roku 2017 przyjęto nowe zasady ustalania kwoty dochodów wolnej od opodatkowania. Z kolei od 1 października $2019 \mathrm{r}$. w pierwszym przedziale skali podatku dochodowego od osób fizycznych zaczęła obowiązywać niższa stawka, zaś wysokość kosztów uzyskania przychodów uległa zwiększeniu.

Celem artykułu jest zbadanie, $w$ jakim stopniu przyjęcie wskazanych regulacji wpłynęło na zmianę poziomu klina podatkowego w Polsce oraz zwiększenie stopnia jego progresywności. W realizacji tak postawionego celu posłużono się metodami analizy opisowej, analizy porównawczej, a także prostymi metodami statystycznymi, w tym miarami średnimi i pozycyjnymi. 
W punkcie 2, na podstawie zbiorczych danych OECD, określono poziom płacowego klina podatkowego w Polsce na tle innych państw wysoko rozwiniętych, a następnie przeprowadzono jego dekompozycję i określono stopień progresji. Kolejny podrozdział zawiera wyniki własnych obliczeń, odzwierciedlające wysokość polskiego klina po wejściu w życie nowych, wspomnianych już regulacji.

Przeprowadzona $w$ artykule analiza odnosi się do pracownika zatrudnionego na umowę o pracę w pełnym wymiarze czasu pracy, uzyskującego różne poziomy dochodu, określone w relacji do przeciętnego wynagrodzenia. Taki zabieg umożliwił ustalenie stopnia progresywności klina podatkowego w Polsce i innych krajach. W opracowaniu pominięto natomiast wpływ sytuacji osobistej, w tym rodzinnej, podatnika na opodatkowanie i oskładkowanie jego wynagrodzeń, dlatego też prezentowane dane dotyczą wysokości płacowego klina podatkowego dla osób niepozostających w związku małżeńskim i nieposiadających małoletnich dzieci.

\section{Pojęcie i struktura klina podatkowego}

Wysokość kosztów pracy stanowi istotną determinantę funkcjonowania podmiotów gospodarczych. Kategoria ta znajduje się w kręgu zainteresowania nie tylko przedsiębiorców, lecz również ekonomistów, polityków czy wreszcie samych obywateli (Krajewska, 2007, s. 7). W definicjach kosztów pracy, prezentowanych w literaturze przedmiotu (Furmańska-Maruszak, 2008, s. 23; Wiktor, 1991, s. 12) oraz w materiałach GUS (2017, s. 13), podkreśla się, że na ich wysokość, obok wynagrodzeń, składają się także elementy pozapłacowe, wśród których zasadnicza rola przypada obciążeniom fiskalnym. W ostatnich latach do analizy poziomu tych obciążeń stosuje się miarę statystyczną, określaną jako tzw. klin podatkowy (Krajewska, 2019, s. 51). W literaturze pojęcia „pozapłacowe koszty pracy” $\mathrm{i}$ „klin podatkowy” są stosowane zamiennie. Podejście takie jest prezentowane również w tym artykule.

Klin podatkowy (tax wedge) jest definiowany jako różnica pomiędzy całkowitymi kosztami ponoszonymi przez pracodawcę w związku z zatrudnieniem pracownika a wynagrodzeniem netto otrzymywanym przez tego pracownika. Wielkość ta może być prezentowana dwojako: w ujęciu bezwzględnym (kwotowo), jak i względnie, tj. w relacji do całkowitych kosztów pracy ponoszonych przez pracodawcę (Biuro Analiz Sądowych, 2008, s. 9). Drugie ze wskazanych ujęć wydaje się szczególnie atrakcyjne poznawczo, ponieważ umożliwia dokonywanie porównań międzynarodowych. Termin „klin podatkowy” jest obecnie stosowany 
przede wszystkim odniesieniu do rynku pracy. W literaturze przedmiotu zwraca się jednak uwagę na fakt, że z klinem podatkowym mamy do czynienia także na rynku towarów i usług, gdzie w związku z nałożeniem podatków pośrednich cena płacona przez konsumenta przewyższa kwotę przychodu uzyskiwanego przez sprzedawcę. Z tej właśnie przyczyny zaleca się, aby w odniesieniu do podatków i składek obciążających wynagrodzenia używać bardziej precyzyjnego pojęcia „płacowy klin podatkowy” (labour tax wedge) (Rosiński, 2013, s. 361-364).

Zgodnie z metodologią OECD, stosowaną do porównań międzynarodowych, płacowy klin podatkowy stanowi sumę obciążeń z tytułu podatku dochodowego od osób fizycznych, składek na ubezpieczenie społeczne finansowanych zarówno przez pracownika, jak i przez pracodawcę, oraz funkcjonujących w niektórych krajach podatków od wynagrodzeń finansowanych przez pracodawców (tzw. payroll taxes), skorygowaną o ewentualne zasiłki. Łączną kwotę tych obciążeń wyraża się jako odsetek całkowitych kosztów pracy (OECD, 2019, s. 21).

W skład płacowego klina podatkowego wchodzą nie tylko podatki w ścisłym tego słowa znaczeniu, lecz również obciążenia parapodatkowe. Składki na ubezpieczenie społeczne różnią się od tradycyjnie rozumianych podatków celowym charakterem - środki z nich uzyskane nie trafiają do budżetu ogólnego, lecz do funduszy celowych, których rolą jest finansowanie określonych świadczeń $\mathrm{z}$ ubezpieczenia społecznego. Tym samym pojęcie opodatkowania w odniesieniu do kosztów pracy należy interpretować szeroko, tj. w sposób zbliżony do prezentowanego w literaturze anglojęzycznej.

Wysokość i struktura płacowego klina podatkowego wywierają istotny wpływ na sytuację na rynku pracy, a w konsekwencji na wzrost gospodarczy. Opodatkowanie pracy prowadzi do zróżnicowania całkowitego kosztu pracy i wynagrodzenia netto otrzymywanego przez pracownika, zaburzając związek pomiędzy kosztem pracy, wynagrodzeniem, a krańcową produktywnością pracy (Góra, Radziwiłł, Sowa \& Walewski, 2006, s. 8). Wysoki poziom klina podatkowego skutkuje zwiększeniem kosztów ponoszonych przez pracodawcę, a jednocześnie obniżeniem wynagrodzenia netto pracowników. Taka sytuacja wpływa negatywnie na rynek pracy, ograniczając popyt na pracę (przedsiębiorcy wstrzymują się z zatrudnianiem nowych pracowników, są skłonni do wprowadzania rozwiązań kapitałochłonnych), a zarazem zmniejszając rozmiary podaży pracy (potencjalni pracownicy nie są dostatecznie zmotywowani do podjęcia pracy). Efektem nałożenia ciężarów fiskalnych na pracę jest ograniczenie oficjalnego zatrudnienia, a w konsekwencji - wzrost bezrobocia. Wysoki poziom płacowego klina podatkowego jest wskazywany jako główna przyczyna rozrostu szarej strefy, a ponadto sprzyja szerzeniu patologii, jak np. zaniżanie oficjalnych wynagrodzeń czy też 
rzekome zatrudnianie w mniejszym wymiarze czasu pracy niż w rzeczywistości (Krajewska, 2016, s. 678). Skutki wysokiego klina podatkowego są szczególnie dotkliwe dla najsłabszych podmiotów rynku pracy: mowa tu zarówno o małych i średnich przedsiębiorstwach występujących w roli pracodawców, jak i o pracownikach nisko wykwalifikowanych, których praca charakteryzuje się najniższą wydajnością, zaś zarobki są najmniejsze (Kasperowicz-Stępień, 2007, s. 73-85).

Sytuacja na rynku pracy jest złożona, zaś poza obciążeniami fiskalnymi poziom zatrudnienia (bezrobocia) jest determinowany szeregiem innych czynników. Niemniej jednak wpływ klina podatkowego na sytuację na rynku pracy jest istotny: w wynikach przeprowadzonych dotąd badań empirycznych oszacowano go na ok. 25-50\% (Biuro Analiz Sądowych, 2007, s. 2).

\section{Poziom i stopień progresywności płacowego klina podatkowego w Polsce na tle innych państw}

Biorąc pod uwagę wyniki porównań międzynarodowych, teza o wysokim poziomie obciążeń fiskalnych nakładanych na pracę nie wydaje się uprawniona. Zgodnie $\mathrm{z}$ danymi publikowanymi przez OECD poziom płacowego klina podatkowego w Polsce w latach 2000-2018 kształtował się w okolicach wartości przeciętnej dla tej organizacji, wahając się w przedziale 34-39\% (rysunek 1).

Na koszt opodatkowania pracy wpływały przede wszystkim regulacje kształtujące wysokość poszczególnych jego elementów. Do roku 2007 wysokość klina w Polsce wynosiła 38-39\%, przewyższając o ok. 1-1,5 pkt. proc. średnią OECD i zbliżając się do mediany. Przeprowadzona dwuetapowo w latach 2007-2008 obniżka stopy składki rentowej o łączną wartość 7 pkt. proc. (1 lipca 2007 r. z 13\% do 10\%, zaś 1 stycznia 2008 r. do 6\%) doprowadziła do redukcji klina o ok. 1,5 pkt. proc., a tym samym do spadku jego wartości poniżej średniej OECD. W 2009 r. trójstopniową skalę podatku dochodowego od osób fizycznych ze stawkami 19\%, $30 \%$ i $40 \%$ zastąpioną skalą dwustopniową z niższymi stawkami (18\% i 32\%), co doprowadziło do dalszego ograniczenia rozmiarów klina. Najniższą wartość płacowego klina podatkowego zanotowano w roku 2009 na poziomie 34,1\%. Klin wzrósł ponownie w roku 2012, kiedy to od 1 lutego zaczęły obowiązywać regulacje zwiększające stopę składki rentowej z 6\% do 8\% ${ }^{2}$. W latach 2013-2018

\footnotetext{
ZUS, Archiwum stóp procentowych.

ZUS, Archiwum stóp procentowych.
} 
Rysunek 1. Poziom płacowego klina podatkowego w Polsce na tle państw OECD

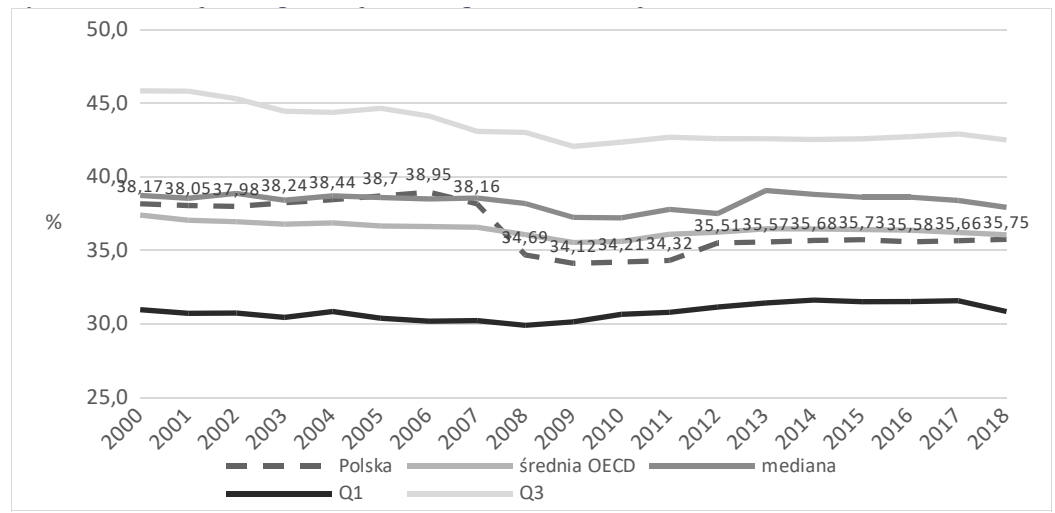

(Źródło: obliczenia własne na podstawie: OECD, Taxing Wages - Comparative Tables).

wysokość płacowego klina podatkowego w Polsce kształtowała się na poziomie zbliżonym do średniej OECD lub ok. 0,5 pkt. proc. od niej niższym.

Należy jednak podkreślić, że metodologia OECD nie bierze pod uwagę wszystkich elementów płacowego klina podatkowego w Polsce, pomijając przy jego obliczaniu część składki przekazywanej do OFE, a także na specjalne subkonto w ZUS. Co więcej, w przypadku Polski, OECD niewłaściwie kalkuluje kwotę podatku PIT, podwójnie potrącając kwotę zmniejszającą podatek (Wojciuk, 2018, s. 143). Realna wartość opodatkowania pracy w Polsce jest zatem wyższa od prezentowanej w statystykach międzynarodowych. Należy także zwrócić uwagę na przeciętny poziom wynagrodzeń, który w przypadku Polski należy do jednych z najniższych w OECD. Przy niskich wynagrodzeniach opodatkowanie i oskładkowanie stają się szczególnie dotkliwie odczuwalne, stąd mogą wynikać opinie przedsiębiorców i samych pracowników na temat kosztów pracy (Rosiński, 2017, s. 156).

Łączna wysokość płacowego klina podatkowego w krajach OECD jest istotnie zróżnicowana, wahając się w przedziale od ok. $7 \%$ w przypadku Chile do ok. 53\% dla Danii. Najwyższe poziomy klina charakteryzują wysoko rozwinięte państwa Europy Zachodniej, realizujące doktrynę państwa opiekuńczego, w tym w szczególności państwa skandynawskie. Nieco niższe opodatkowanie pracy występuje w państwach Europy Środkowo-Wschodniej, krajach o tzw. południowej mentalności podatkowej oraz państwach pozaeuropejskich. Chile stanowi szczególny przypadek, gdyż w kraju tym skala PIT została skonstruowana w ten sposób, że kwotę wolną od podatku ustanowiono na bardzo wysokim poziomie, tylko nieznacznie niższym od przeciętnego wynagrodzenia w gospodarce. Po 
uwzględnieniu odliczeń z tytułu opłaconych składek, pracownik uzyskujący płacę równą „średniej krajowej” jest wolny od podatku dochodowego, zaś jedyny ciężar nakładany na jego wynagrodzenie stanowi ubezpieczenie społeczne finansowane przez pracodawcę (OECD, 2019, s. 239-248).

Podsumowując, zasadniczymi czynnikami warunkującymi wysokość płacowego klina podatkowego pozostają: realizowany model polityki społeczno-gospodarczej, w tym programy publiczne oferujące zabezpieczenie społeczne obywateli, oraz międzynarodowa konkurencja podatkowa. Istotną rolę odgrywa również kondycja finansów publicznych w danym państwie, gdyż wysokość obciążeń fiskalnych nakładanych na pracę istotnie wpływa na sumaryczną kwotę dochodów uzyskiwanych przez jednostki sektora General Government, a w konsekwencji na wynik finansowy tego sektora (Rosiński, 2013, s. 367). Kolejny czynnik warunkujący wysokość podatkowego obciążenia pracy to postępujący proces starzenia się społeczeństw, obserwowany przede wszystkim w państwach wysoko rozwiniętych.

Przechodząc do omówienia wewnętrznej struktury płacowego klina podatkowego należy przyznać, że w przypadku Polski jest ona niestandardowa i odbiega od rozwiązań stosowanych w większości krajów OECD. Obciążenie z tytułu PIT zawarte w polskim klinie podatkowym należy uznać za wyjątkowo niskie - w latach 2000-2018 wahało się ono w przedziale 6,1-7,4\%, kształtując się poniżej wartości pierwszego kwartyla dla państw OECD, a zarazem odbiegając o 8-10 pkt. proc. in minus od wartości przeciętnej dla tej organizacji. Aby znaleźć przyczyny takiego stanu rzeczy, należy odwołać się do początków reformy podatkowej w Polsce. Podatek dochodowy od osób fizycznych wprowadzono w roku 1992 w warunkach transformacji gospodarczej. Aby wdrożyć ten instrument sprawnie, bez zbędnego oporu społecznego, skalę podatkową skonstruowano w ten sposób, by zdecydowana większość podatników (ponad 90\%) znalazła się w pierwszym jej przedziale i została objęta relatywnie niską, 20-procentową stawką (Krajewska, 2019, s. 55). W 2009 r. zreformowano skalę podatku dochodowego od osób fizycznych w Polsce, wprowadzając dwie stawki: $18 \%$ i $32 \%$. Reforma była pokłosiem procesu międzynarodowej konkurencji podatkowej, który wyraźnie zaznaczył się na kontynencie europejskim po 2000 roku i doprowadziła do dalszego obniżenia udziału PIT w płacowym klinie podatkowym. W efekcie w 2018 r. Polska znalazła się na trzydziestym czwartym miejscu wśród państw OECD pod względem poziomu klina podatkowego z tytułu podatku dochodowego od osób fizycznych. Niższe obciążenie PIT-em pracownika uzyskującego wynagrodzenie równe przeciętnej płacy w gospodarce, zanotowano tylko w Chile oraz w Korei. 
Obciążenia z tytułu składek na ubezpieczenie społeczne są w Polsce relatywnie wysokie. Do roku 2007 ich wartość, zawarta w placowym klinie podatkowym dla pracownika uzyskującego wynagrodzenie równe średniej krajowej, oscylowała

Rysunek 2. Obciążenie z tytułu PIT zawarte w płacowym klinie podatkowym w relacji do całkowitych kosztów pracy w Polsce na tle państw OECD

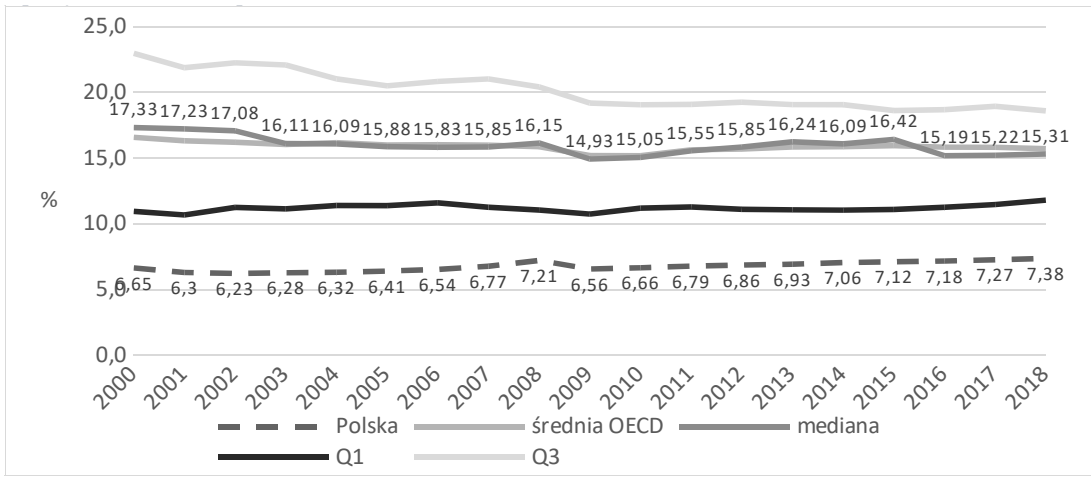

(Źródło: obliczenia własne na podstawie: OECD, Taxing Wages - Comparative Tables).

Rysunek 3. Obciążenie z tytułu składek na ubezpieczenie społeczne (suma składek pracownika i pracodawcy) zawarte w płacowym klinie podatkowym w relacji do całkowitych kosztów pracy w Polsce na tle państw OECD

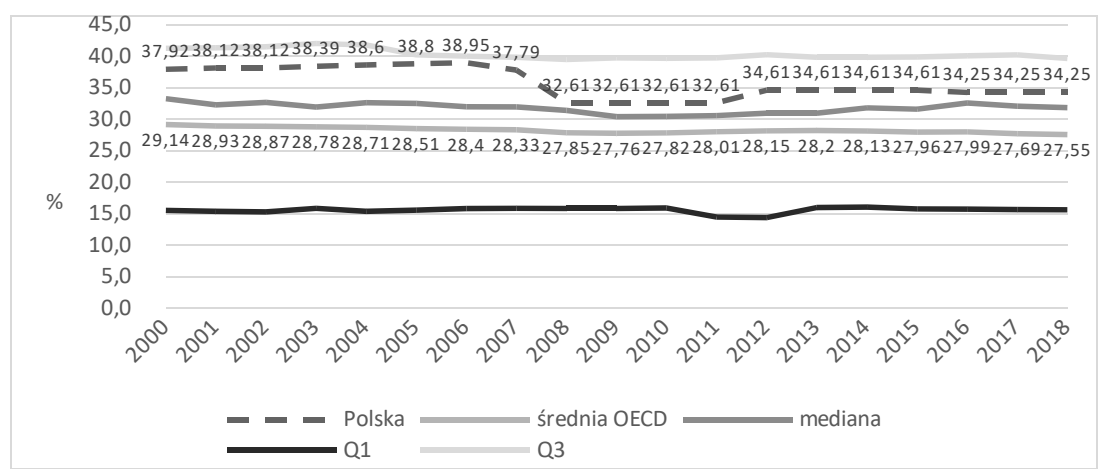

(Źródło: obliczenia własne na podstawie: OECD, Taxing Wages - Comparative Tables).

w granicach trzeciego kwartyla dla państw OECD, a jednocześnie przewyższała przeciętną wartość o ok. 9-11 pkt. proc. W 2008 r. przeprowadzono wspomnianą już obniżkę stawki rentowej, co sprawiło, że rozpiętość między wysokością składek w Polsce a średnią OECD uległa niewielkiemu ograniczeniu.

Wewnętrzna struktura płacowego klina podatkowego w państwach OECD jest istotnie zróżnicowana. Wchodzące w skład klina podatek dochodowy od 
osób fizycznych oraz składki na ubezpieczenie społeczne nie podlegają procesom harmonizacji na poziomie ponadnarodowym. Co więcej, poszczególne kraje nie wypracowały międzynarodowych standardów w zakresie ich konstrukcji. Biorąc pod uwagę wartości przeciętne dla OECD, dominujący element obciążeń fiskalnych nakładanych na pracę stanowią składki ubezpieczenia społecznego, których udział w całości klina wynosi ok. 60\%. W krajach takich jak Chile, Korea czy Polska ich dominacja w klinie jest jeszcze wyraźniejsza, zaś udział PIT w fiskalnym obciążeniu wynagrodzeń - marginalny. Z drugiej strony, w Nowej Zelandii system ubezpieczeń społecznych w ogóle się nie wykształcił, zaś w Danii funkcjonuje w ograniczonym zakresie. Do niedawna nieobecny był także w Australii (OECD, Taxing Wages - Comparative Tables).

Z punktu widzenia wysokości płacowego klina podatkowego jego wewnętrzna struktura nie odgrywa większego znaczenia, zaś współwystępujące w klinie podatek dochodowy od osób fizycznych i składki na ubezpieczenie społeczne mają charakter komplementarny. W wielu krajach (m.in. Nowa Zelandia, Dania, Belgia, Francja, Litwa) świadczenia z ubezpieczeń społecznych są finansowane nie tylko środkami zgromadzonymi w funduszach ubezpieczeń społecznych, lecz również wpływami z PIT czy innych podatków (Mazurek-Chwiejczak, 2016a, s. 172-174). Podobna sytuacja występuje także w Polsce w związku z przekazywaniem znacznych kwot dotacji z budżetu państwa na rzecz Funduszu Ubezpieczeń Społecznych, Funduszu Emerytalno-Rentowego oraz innych funduszy, z których wypłacane są świadczenia z ubezpieczeń społecznych³.

Można natomiast stwierdzić występowanie zależności pomiędzy strukturą płacowego klina podatkowego a stopniem jego progresji. Podatek (klin podatkowy) można określić jako progresywny, jeśli pochłania on relatywnie większą część dochodu osób o wyższych dochodach w porównaniu z osobami uzyskującymi niższe zarobki (OECD, 2012, s. 3). Określenie stopnia progresywności płacowego klina podatkowego, jak i poszczególnych jego elementów, jest możliwe dzięki porównaniu wysokości obciążeń dla pracownika osiągającego wynagrodzenie równe $167 \%$ przeciętnej płacy z obciążeniami dla pracownika zarabiającego $67 \%$ przeciętnego wynagrodzenia (tabela 1).

3 Przekazana z budżetu państwa do FUS dotacja wyniosła w 2018 r. blisko 36 mld zł, dotacja do FER - przekroczyła 17 mld zł, dotacja do Funduszu Emerytur Pomostowych wyniosła ponad 550 mln zł, zaś do Funduszu Prewencji i Rehabilitacji - 5 mln zł. Szerzej: Rada Ministrów, 2019, s. 88. 
Tabela 1. Mierniki progresywności klina podatkowego w państwach OECD w $2018 \mathrm{r}$.

\begin{tabular}{|c|c|c|c|c|c|c|c|c|c|}
\hline \multirow{2}{*}{$\begin{array}{c}\begin{array}{c}\text { Wyszczegól- } \\
\text { nienie }\end{array} \\
\begin{array}{c}\text { Poziom płacy } \\
\text { jako odsetek } \\
\text { przeciętnego } \\
\text { wynagrodzenia }\end{array}\end{array}$} & \multicolumn{3}{|c|}{$\begin{array}{l}\text { Łączna wartość płacowego } \\
\text { klina podatkowego }\end{array}$} & \multicolumn{3}{|c|}{ Komponent PIT } & \multicolumn{3}{|c|}{$\begin{array}{l}\text { Komponent składek na } \\
\text { ubezpieczenie społeczne }\end{array}$} \\
\hline & $67 \%$ & $167 \%$ & $\begin{array}{c}\text { Różnica } \\
\text { między } \\
167 \% \\
\text { a } 67 \%\end{array}$ & $67 \%$ & $167 \%$ & $\begin{array}{c}\text { Różnica } \\
\text { między } \\
167 \% \\
\text { a } 67 \%\end{array}$ & $67 \%$ & $167 \%$ & $\begin{array}{c}\text { Różnica } \\
\text { między } \\
167 \% \\
\text { a } 67 \%\end{array}$ \\
\hline 1 & 2 & 3 & 4 & 5 & 6 & 7 & 8 & 9 & 10 \\
\hline Irlandia & 24,2 & 32,7 & 41,5 & 17,3 & 11,9 & 21,4 & 31,1 & 19,2 & 14,9 \\
\hline Izrael & 15,5 & 22,4 & 31,8 & 16,4 & 5,4 & 10,0 & 17,8 & 12,4 & 10,8 \\
\hline Luksemburg & 30,4 & 38,2 & 45,5 & 15,1 & 8,4 & 17,2 & 25,5 & 17,1 & 26,2 \\
\hline Włochy & 40,9 & 47,9 & 54,0 & 13,1 & 12,8 & 21,9 & 29,8 & 17,1 & 41,1 \\
\hline Belgia & 46,1 & 52,7 & 59,0 & 12,9 & 18,2 & 25,9 & 33,9 & 15,7 & 39,8 \\
\hline Finlandia & 36,1 & 42,3 & 48,6 & 12,5 & 12,6 & 20,2 & 27,8 & 15,2 & 31,2 \\
\hline Holandia & 30,8 & 37,7 & 42,2 & 11,4 & 6,8 & 17,5 & 28,2 & 21,4 & 27,6 \\
\hline W. Brytania & 26,1 & 30,9 & 37,3 & 11,2 & 11,0 & 14,0 & 22,3 & 11,3 & 17,6 \\
\hline Francja & 43,1 & 47,6 & 54,1 & 11,0 & 13,0 & 16,8 & 22,9 & 9,9 & 43,8 \\
\hline Szwecja & 41,0 & 43,1 & 51,8 & 10,8 & 15,5 & 18,2 & 32,0 & 16,5 & 38,4 \\
\hline Australia & 24,1 & 28,9 & 34,3 & 10,2 & 19,6 & 24,6 & 30,4 & 10,8 & 6,0 \\
\hline N. Zelandia & 13,8 & 18,4 & 24,0 & 10,2 & 13,8 & 18,4 & 24,0 & 10,2 & 0,0 \\
\hline Grecja & 36,9 & 40,9 & 46,6 & 9,7 & 5,1 & 10,1 & 17,2 & 12,1 & 41,1 \\
\hline Portugalia & 36,5 & 40,7 & 46,0 & 9,5 & 10,4 & 15,6 & 22,2 & 11,8 & 34,8 \\
\hline Norwegia & 32,8 & 35,8 & 41,6 & 8,9 & 15,8 & 19,3 & 25,8 & 10,0 & 21,2 \\
\hline Dania & 33,2 & 35,7 & 41,5 & 8,3 & 33,5 & 35,8 & 41,5 & 8,1 & 0,0 \\
\hline Estonia & 32,9 & 36,5 & 41,2 & 8,3 & 8,6 & 13,4 & 19,7 & 11,1 & 35,4 \\
\hline Turcja & 34,2 & 38,9 & 42,5 & 8,2 & 9,6 & 13,2 & 17,4 & 7,8 & 29,6 \\
\hline Islandia & 30,1 & 33,2 & 38,0 & 7,9 & 24,9 & 28,4 & 33,6 & 8,7 & 7,2 \\
\hline Hiszpania & 35,9 & 39,4 & 43,8 & 7,9 & 10,4 & 14,9 & 20,7 & 10,3 & 36,3 \\
\hline Austria & 43,3 & 47,6 & 50,9 & 7,7 & 9,3 & 14,8 & 21,6 & 12,3 & 46,3 \\
\hline Szwajcaria & 19,5 & 22,2 & 26,9 & 7,4 & 8,2 & 11,2 & 16,1 & 7,9 & 12,5 \\
\hline Słowenia & 40,0 & 43,3 & 46,7 & 6,7 & 8,2 & 12,0 & 16,0 & 7,8 & 38,2 \\
\hline Meksyk & 16,1 & 19,7 & 22,7 & 6,6 & 3,2 & 8,9 & 13,4 & 10,2 & 15,1 \\
\hline $\begin{array}{l}\text { Stany } \\
\text { Zjednoczone }\end{array}$ & 27,6 & 29,6 & 34,1 & 6,5 & 13,7 & 16,1 & 21,1 & 7,4 & 16,2 \\
\hline Kanada & 25,8 & 30,7 & 32,1 & 6,2 & 11,9 & 15,7 & 21,6 & 9,7 & 18,0 \\
\hline Niemcy & 45,4 & 49,5 & 51,3 & 5,9 & 14,1 & 19,1 & 27,6 & 13,5 & 40,0 \\
\hline Korea & 19,8 & 23,0 & 25,4 & 5,6 & 3,0 & 6,4 & 11,7 & 8,7 & 19,0 \\
\hline Litwa & 37,1 & 40,6 & 42,1 & 5,0 & 8,5 & 13,1 & 15,0 & 6,5 & 40,2 \\
\hline Czechy & 41,4 & 43,7 & 45,7 & 4,3 & 10,4 & 13,6 & 16,2 & 5,8 & 45,0 \\
\hline
\end{tabular}




\begin{tabular}{|l|r|r|r|r|r|r|r|r|r|}
\hline \multicolumn{1}{|c|}{$\mathbf{1}$} & $\mathbf{2}$ & \multicolumn{1}{c|}{$\mathbf{3}$} & $\mathbf{4}$ & $\mathbf{5}$ & $\mathbf{6}$ & \multicolumn{1}{c|}{$\mathbf{7}$} & $\mathbf{8}$ & $\mathbf{9}$ & \multicolumn{1}{c|}{$\mathbf{1 0}$} \\
\hline Słowacja & 39,5 & 41,7 & 43,6 & $\mathbf{4 , 1}$ & 7,5 & 10,5 & 12,9 & $\mathbf{5 , 4}$ & 44,1 \\
\hline Łotwa & 38,7 & 42,3 & 42,6 & $\mathbf{4 , 0}$ & 12,8 & 17,4 & 17,8 & $\mathbf{5 , 0}$ & 35,1 \\
\hline Japonia & 31,2 & 32,6 & 35,1 & $\mathbf{4 , 0}$ & 6,2 & 7,9 & 12,9 & $\mathbf{6 , 7}$ & 29,7 \\
\hline Chile & 7,0 & 7,0 & 8,3 & $\mathbf{1 , 3}$ & 0,0 & 0,0 & 1,3 & $\mathbf{1 , 3}$ & 7,0 \\
\hline Polska & 35,1 & 35,8 & 36,3 & $\mathbf{1 , 1}$ & 6,7 & 7,4 & 8,0 & $\mathbf{1 , 3}$ & 34,2 \\
\hline Węgry & 45,0 & 45,0 & 45,0 & $\mathbf{0 , 0}$ & 15,0 & 15,0 & 15,0 & $\mathbf{0 , 0}$ & 39,5 \\
\hline Srednia OECD & 32,1 & 40,4 & $\mathbf{8 , 3}$ & 11,3 & 21,4 & $\mathbf{1 0 , 2}$ & 27,3 & 26,8 & $\mathbf{- 0 , 5}$ \\
\hline $\begin{array}{l}\text { Mediana } \\
\text { OECD }\end{array}$ & 33,7 & 42,1 & $\mathbf{8 , 1}$ & 10,4 & 21,4 & $\mathbf{1 0 , 1}$ & 30,5 & 31,4 & $\mathbf{0 , 0}$ \\
\hline
\end{tabular}

(Źródło: obliczenia własne na podstawie: OECD, Taxing Wages - Comparative Tables).

Zgodnie z przytoczoną definicją klin płacowy można uznać za progresywny we wszystkich krajach OECD z wyjątkiem Węgier. Przeciętnie w całej tej organizacji stopa łącznego opodatkowania i oskładkowania wynagrodzenia osoby uzyskującej wynagrodzenie równe $167 \%$ średniej krajowej była w 2018 r. wyższa o 8,3 pkt. proc. w porównaniu z osobą zarabiającą 67\% średniej krajowej. Najwyższy stopień progresji (różnica w stopach opodatkowania dla wskazanych poziomów dochodu przekraczająca 10 pkt. proc.) charakteryzował systemy podatkowe Irlandii, Izraela, Luksemburga, Włoch, Belgii, Finlandii, Holandii, Wielkiej Brytanii, Francji, Szwecji, Australii i Nowej Zelandii. W Polsce płacowy klin podatkowy dla osoby uzyskującej wynagrodzenie na poziomie $167 \%$ przeciętnego wynagrodzenia był w 2018 r. jedynie minimalnie (o 1,1 pkt. proc.) wyższy w porównaniu z klinem dla osoby, której płaca wynosi 67\% średniej krajowej. Niższą wartość omawianego miernika progresywności zanotowano jedynie w przypadku wspomnianych już Węgier, gdzie obowiązuje liniowa skala podatku PIT przy jednoczesnym braku kwoty wolnej od opodatkowania (Mazurek-Chwiejczak, 2016b, s. 181-193). Z kolei w pozostałych państwach stosujących liniowy systemy opodatkowania dochodów osobistych (Czechy, Estonia, Litwa ${ }^{4}$, Łotwa) stopień progresji klina płacowego jest wyższy w porównaniu z Polską. Przyczyn takiego stanu należy upatrywać w konstrukcji skali polskiego podatku dochodowego od osób fizycznych, w której założono dość wysoki poziom progu podatkowego. Jak wynika z danych Ministerstwa Finansów w 2017 r. aż ok. 96,5\% podatników PIT rozliczających się na zasadach ogólnych nie przekroczyło wspomnianego progu, płacąc podatek według niższej, 18-procentowej stawki (Ministerstwo Finansów, 2018, s. 9).

4 Od 1 stycznia 2019 r. na Litwie funkcjonują dwa przedziały skali podatku PIT, jednak w 2018 r., dla którego prezentowane są dane w tabeli 1, obowiązywał tam system liniowy. 
Elementem klina podatkowego decydującym o jego progresywności jest podatek dochodowy od osób fizycznych. Jak wynika z tabeli 1, stopień progresji PIT zawartego w płacowym klinie podatkowym jest wyższy niż w przypadku całkowitego klina, zaś różnica przeciętnych wartości stóp dla analizowanych poziomów dochodów Z wynagrodzeń wynosi 10,2 pkt. proc. Z kolei systemy składek na ubezpieczenie społeczne w większości państw OECD (w 20 krajach) mają charakter proporcjonalny, pochłaniając taką samą część wynagrodzenia niezależnie od poziomu uzyskiwanych dochodów. Jedynie we Francji Belgii, Izraelu, Luksemburgu, Turcji, Włoszech i Wielkiej Brytanii składki na ubezpieczenie społeczne mają charakter progresywny. Z kolei w 10 państwach OECD systemy te charakteryzują się regresją.

\section{Wpływ nowych rozwiązań w konstrukcji podatku dochodowego od osób fizycznych na poziom i strukturę płacowego klina podatkowego w Polsce}

Skala obowiązującego w Polsce podatku dochodowego od osób fizycznych pozostawała niezmieniona począwszy od 2009 r. do roku 2016. 1 stycznia 2017 r. wprowadzono nową metodę wyznaczania kwoty wolnej od podatku, opartą na degresywnej formule. Niezmiennie od 2009 r. w konstrukcji skali PIT przewidziane były dwa przedziały skali podatkowej ze stawkami wynoszącymi $18 \%$ i $32 \%$ oraz progiem podatkowym ustanowionym na poziomie $85528 \mathrm{zł}$. Od 1 października 2019 r. obowiązuje nowa skala PIT, która różni się od poprzedniej niższą 01 pkt. proc., tj. 17-procentową stawką obowiązującą w pierwszym przedziale skali podatkowej. Stawka w drugim przedziale skali, jak i kwota progu podatkowego pozostały niezmienione. $\mathrm{W}$ efekcie tych reform stawka podatku dochodowego od osób fizycznych obowiązująca w pierwszym progu skali w rozliczeniu rocznym za $2019 \mathrm{r}$. wyniesie $17,75 \%$, z kolei począwszy od rozliczenia za 2020 r. będzie obowiązywać nowa 17-procentowa stawka5.

1 października 2019 r. zaczęły obowiązywać również wyższe kwoty kosztów uzyskania przychodów. W latach 2008-2018 oraz przez pierwsze dziewięć miesięcy 2019 r. miesięczna wysokość kosztów dla osoby uzyskującej wynagrodzenie z jednego stosunku pracy wynosiła 111,25 zł przy założeniu, że osoba ta nie dojeżdża do pracy z innej miejscowości oraz 139,06 zł dla osoby dojeżdżającej.

5 Ustawa z dnia 30 sierpnia 2019 r. o zmianie ustawy o podatku dochodowym od osób fizycznych oraz ustawy o zmianie ustawy o podatku dochodowym od osób fizycznych oraz niektórych innych ustaw (Dz.U. z 2019 r. poz. 1835), art. 1 ust. 1. 
Po wejściu w życie nowych przepisów wysokość kosztów wynosi odpowiednio $250 \mathrm{zł}$ i $300 \mathrm{zł}$ miesięcznie 6 .

Ponadto od 1 sierpnia 2019 r. w podatku PIT obowiązuje ulga, polegająca na zwolnieniu z opodatkowania przychodów ze stosunku pracy i z umów zlecenia dla osób, które nie ukończyły 26. roku życia.

Na rysunku 4 i w tabeli 2 zawarto obliczenia dotyczące wysokości płacowego klina podatkowego w Polsce w latach 2018-2020. Analiza dotyczyła pracownika zatrudnionego na umowę o pracę w pełnym wymiarze czasu pracy, uzyskującego wynagrodzenie różnej wysokości (określone jako odsetek średniej płacy). Do obliczeń wykorzystano dane dotyczące przeciętnego wynagrodzenia w gospodarce publikowane w komunikacie Prezesa GUS (dla roku 2018 - GUS, 2019) oraz prognozy przeciętnego miesięcznego wynagrodzenia zawarte w obwieszczeniach Ministra Rodziny, Pracy i Polityki Społecznej (dla lat 2019-2020 - Ministerstwo Rodziny, Pracy i Polityki Społecznej, 2018, 2019). Należy podkreślić, że wyznaczony poziom klina podatkowego nie pokrywa się z danymi publikowanymi przez OECD, gdyż, jak już wspomniano, metodologia OECD nie uwzględnia w przypadku Polski wszystkich elementów podatkowych kosztów pracy.

Rysunek 4. Poziom płacowego klina podatkowego w Polsce w zależności od wysokości wynagrodzenia w latach 2018-2020

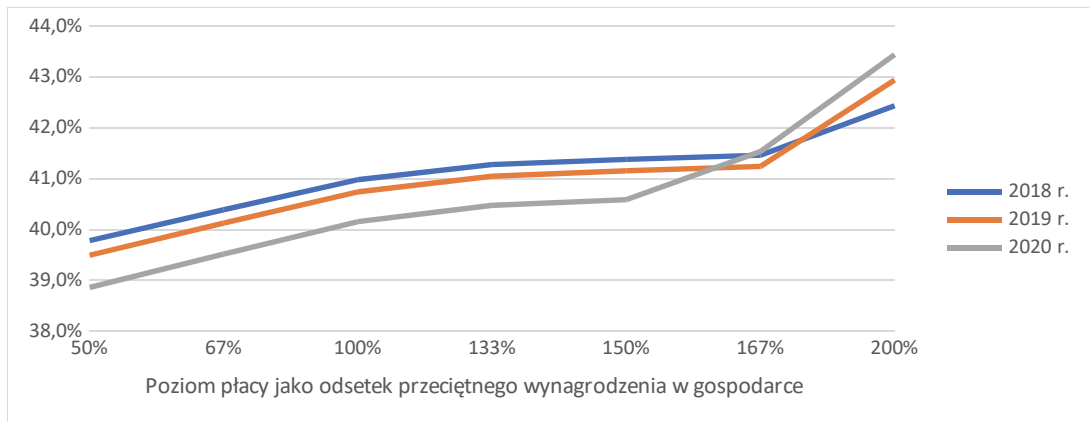

(Źródło: obliczenia własne na podstawie Ustawy z dnia 26 lipca 1991 r. o podatku dochodowym od osób fizycznych, Ustawy z dnia 13 października 1998 r. o systemie ubezpieczeń społecznych oraz Ustawy z dnia 30 października 2002 r. o ubezpieczeniu społecznym z tytułu wypadków przy pracy i chorób zawodowych).

6 Ustawa z dnia 30 sierpnia 2019 r. o zmianie ustawy o podatku dochodowym od osób fizycznych oraz ustawy o zmianie ustawy o podatku dochodowym od osób fizycznych oraz niektórych innych ustaw (Dz.U. 2019, poz. 1835), art. 1 ust. 3, art. 5.

7 Zwolnieniu z opodatkowania podlegają przychody do łącznej kwoty $85528 \mathrm{zł}$ w roku podatkowym. Szerzej: Ustawa z dnia 26 lipca 1991 r. o podatku dochodowym od osób fizycznych (Dz.U. z 2019 r. poz. 1387 ze zm.), art. 21 ust. 148. 
Z przeprowadzonych wyliczeń wynika, że poziom płacowego klina podatkowego dla osób uzyskujących płacę w przedziale 50-150\% średniego wynagrodzenia wyznaczony dla roku 2020 zmniejszył się o ok. 0,8-0,9 pkt. proc. w porównaniu $\mathrm{z}$ klinem obliczonym dla tej samej grupy dla roku 2018. Redukcja klina w tym przedziale dochodowym, choć nastąpiła, to jednak miała marginalne znaczenie. Z kolei opodatkowanie pracy dla osób uzyskujących wynagrodzenie równe $167 \%$ i 200\% średniej krajowej nieznacznie wzrosło. W efekcie zwiększeniu uległy mierniki stopnia progresji klina podatkowego. Różnica między poziomem klina dla osoby uzyskującej wynagrodzenie równe $167 \%$ średniej płacy w porównaniu z osobą, której wynagrodzenie wynosi 67\% średniej krajowej, wzrosła z 1,1 pkt. proc. do 2 pkt. proc. Jeszcze większy wzrost (z 2,7 pkt. proc. do 4,6 pkt. proc.) był obserwowany dla różnicy w poziomie klina dla osób uzyskujących $200 \%$ i $50 \%$ średniej krajowej.

Mimo zanotowanych zmian stopień progresywności polskiego klina podatkowego w dalszym ciągu pozostaje minimalny i nie należy się spodziewać, że zmiany regulacji w zakresie podatku dochodowego od osób fizycznych wpłyną zasadniczo na poprawę pozycji Polski w porównaniach międzynarodowych. Przeprowadzone reformy miały raczej charakter ewolucyjny i nie doprowadzily ani do istotnej redukcji płacowego klina podatkowego, ani też do wzrostu stopnia jego progresji. Skutkowały one jedynie niewielkim zmniejszeniem wysokości klina dla osób uzyskujących relatywnie niskie, przeciętne bądź nieco wyższe od przeciętnych dochody. Obserwowany wzrost klina dla osób o wysokich zarobkach stanowi rezultat zwiększenia ogólnego poziomu wynagrodzeń w gospodarce, który skutkuje tym, że podatnik uzyskujący $167 \%$ czy $200 \%$ przeciętnego wynagrodzenia musi większą część swojego dochodu opodatkować wyższą, 32-procentową stawką. Polski klin płacowy, jak i podatek dochodowy od osób fizycznych, w dalszym ciągu nie pełnią funkcji redystrybucyjnej. Taka sytuacja może być szczególnie dotkliwa dla osób o niskich zarobkach, które mogą mieć problem z utrzymaniem się na rynku pracy. 
Tabela 2. Poziom i struktura płacowego klina podatkowego w Polsce w zależności od wysokości wynagrodzenia w latach 2018-2020

\begin{tabular}{|c|c|c|c|c|c|c|c|c|c|c|}
\hline Wyszczególnienie & 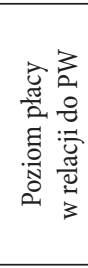 & 今े & ฉ̊ & ळे & $\stackrel{\text { ஸे }}{\stackrel{n}{n}}$ & $\begin{array}{l}\text { 今े } \\
\text { in }\end{array}$ & 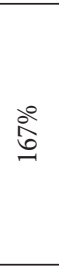 & 今े & 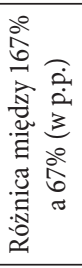 & 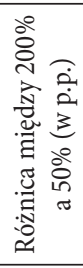 \\
\hline \multirow{3}{*}{$\begin{array}{l}\text { Całkowita wartość } \\
\text { płacowego klina } \\
\text { podatkowego }\end{array}$} & $2018 \mathrm{r}$. & 39,8 & 40,4 & 41,0 & 41,3 & 41,4 & 41,5 & 42,4 & 1,1 & 2,7 \\
\hline & $2019 \mathrm{r}$. & 39,5 & 40,1 & 40,7 & 41,0 & 41,2 & 41,2 & 42,9 & 1,1 & 3,4 \\
\hline & $2020 \mathrm{r}$. & 38,9 & 39,5 & 40,2 & 40,5 & 40,6 & 41,5 & 43,4 & 2,0 & 4,6 \\
\hline \multirow{3}{*}{ Komponent PIT } & $2018 \mathrm{r}$. & 4,9 & 5,5 & 6,1 & 6,4 & 6,5 & 6,6 & 7,6 & 1,1 & 2,7 \\
\hline & $2019 \mathrm{r}$. & 4,7 & 5,3 & 5,9 & 6,2 & 6,3 & 6,4 & 8,1 & 1,1 & 3,4 \\
\hline & $2020 \mathrm{r}$. & 4,0 & 4,7 & 5,3 & 5,7 & 5,8 & 6,7 & 8,6 & 2,0 & 4,6 \\
\hline \multirow{3}{*}{$\begin{array}{l}\text { Komponent skła- } \\
\text { dek na ubezpie- } \\
\text { czenie społeczne } \\
\text { i zdrowotne }\end{array}$} & $2018 \mathrm{r}$. & 34,8 & 34,8 & 34,8 & 34,8 & 34,8 & 34,8 & 34,8 & 0,0 & 0,0 \\
\hline & $2019 \mathrm{r}$. & 34,8 & 34,8 & 34,8 & 34,8 & 34,8 & 34,8 & 34,8 & 0,0 & 0,0 \\
\hline & $2020 \mathrm{r}$. & 34,8 & 34,8 & 34,8 & 34,8 & 34,8 & 34,8 & 34,8 & 0,0 & 0,0 \\
\hline
\end{tabular}

(Źródło: jak w rysunku 4).

$\mathrm{PW}$ - przeciętne wynagrodzenie w gospodarce

Dane $\mathrm{w}$ tabeli podano $\mathrm{w} \%$.

Należy też podkreślić, że implementacja nowych zasad określania kwoty wolnej od podatku $\mathrm{z}$ dniem 1 stycznia $2017 \mathrm{r}$. nie przyniosła istotnych zmian w zakresie klina podatkowego. W wyniku nowych regulacji dochód do kwoty 8000 zł jest całkowicie wolny od podatku dochodowego, kwota wolna od opodatkowania stopniowo się zmniejsza w przedziale dochodów od 8000 zł do $13000 \mathrm{zl}$, dla dochodów w granicach 13000 zł - 85528 zł kwota wolna wynosi 3091 zł, dla dochodów z przedziału 85528 zł - 127000 zł kwota ta ponownie ulega stopniowej redukcji, zaś dla dochodu przekraczającego 127000 zł kwota ta w ogóle nie obowiązuje, co oznacza, że pełna wysokość dochodu podlega opodatkowaniů . Mimo że kierunek podjętych zmian wydaje się słuszny, to jednak można przypuszczać, że dla większości podatników PIT dochód podlegający opodatkowaniu mieści się w przedziale 13000 zł - 85525 zl, dla którego poziom kwoty dochodów wolnej od opodatkowania pozostał niezmieniony. Wydaje się, że omawiany instrument nie jest w Polsce wykorzystywany w dostatecznym stopniu do realizacji polityki podatkowej. Ustanowienie kwoty wolnej od podatku na odpowiednio wysokim poziomie może wywołać efekt progresji ukrytej i zwiększyć właściwości redys-

\footnotetext{
8 Ustawa z dnia 26 lipca 2019 r. o podatku dochodowym od osób fizycznych, art. 27, ust. 1a.
} 
trybucyjne zarówno podatku dochodowego od osób fizycznych, jak i całego klina podatkowego. Świadczyć mogą o tym przykłady państw stosujących liniowe opodatkowanie dochodów osobistych, dla których stopień progresji klina płacowego jest wyższy niż w Polsce (np. Czechy, Estonia, Łotwa).

\section{Podsumowanie}

Na podstawie przeprowadzonej analizy danych statystycznych, jak również w wyniku badań własnych, można sformułować następujące wnioski:

1. Wysokość płacowego klina podatkowego w Polsce dla osoby uzyskującej płacę równą przeciętnemu wynagrodzeniu w gospodarce kształtuje się na poziomie zbliżonym do średniej OECD.

2. Wewnętrzna struktura płacowego klina podatkowego jest w Polsce nietypowa i charakteryzuje się, z jednej strony, wyjątkowo niskim udziałem podatku dochodowego od osób fizycznych (niższy udział PIT w klinie występuje jedynie w Chile i w Korei), z drugiej zaś - znacznym odsetkiem składek na ubezpieczenie społeczne.

3. Stopień progresji płacowego klina podatkowego w Polsce należy do najniższych w OECD. Poziom klina dla osoby uzyskującej płacę równą 167\% średniego wynagrodzenia jest niemalże taki sam jak w przypadku pracownika, którego wynagrodzenie wynosi $67 \%$ średniej krajowej. Udział podatku dochodowego w klinie podatkowym jest w Polsce szczególnie niski, przy czym PIT pozostaje jedynym elementem klina przyczyniającym się do jego progresywności. Jedną z przyczyn takiego stanu może stanowić niewłaściwie skonstruowana skala podatku dochodowego od osób fizycznych, z progiem podatkowym ustanowionym na tak wysokim poziomie, że jedynie ok. 3,5\% podatników płaci podatek według wyższej, 32-procentowej stawki.

4. Przeprowadzone w 2019 r. reformy konstrukcji PIT, polegające przede wszystkim na zmianie skali podatkowej oraz podwyższeniu kosztów uzyskania przychodów, w niewielkim stopniu przyczyniły się do zmniejszenia płacowego klina podatkowego. Zmiana w wysokości klina dotyczyła przede wszystkim podatników osiągających niskie i przeciętne dochody. Nie wzrosła również zasadniczo progresywność klina. Swojej roli nie odgrywa też w należyty sposób kwota wolna od podatku, ustalana począwszy od 2017 r. według nowych zasad, opartych na degresywnej formule.

5. Obecny poziom i struktura płacowego klina podatkowego mogą wywoływać negatywne skutki, w szczególności dla pracowników niewykwalifikowanych, 
uzyskujących relatywnie niewielkie wynagrodzenie. Osoby takie mają bowiem problem z wejściem na rynek pracy i utrzymaniem się na nim. Wysoki poziom klina dla tej grupy może skutkować wzrostem bezrobocia, a w konsekwencji przyczyniać się do pogłębiania ubóstwa. Należy zatem poszukiwać możliwości zmniejszenia klina, w szczególności dla osób o niewielkich dochodach. Atrakcyjnym rozwiązaniem może być podwyższenie kwoty wolnej od podatku, dające efekt progresji ukrytej.

\section{Bibliografia}

\section{Akty normatywne}

Ustawa z dnia 26 lipca 1991 r. o podatku dochodowym od osób fizycznych (Dz.U. z 2019 r., poz. 1387 z późn. zm.).

Ustawa z dnia 13 października 1998 r. o systemie ubezpieczeń społecznych (Dz.U. z 2019 r., poz. 300, z późn. zm.).

Ustawa z dnia 30 sierpnia 2019 r. o zmianie ustawy o podatku dochodowym od osób fizycznych oraz ustawy o zmianie ustawy o podatku dochodowym od osób fizycznych oraz niektórych innych ustaw (Dz.U. z 2019 r. poz. 1835).

Ustawa z dnia 30 października 2002 r. o ubezpieczeniu społecznym z tytułu wypadków przy pracy i chorób zawodowych (Dz.U. z 2018 r. poz. 1376, z późn. zm.).

GUS (2019). Komunikat Prezesa Głównego Urzędu Statystycznego $z$ dnia 11 lutego $2019 \mathrm{r}$. w sprawie przeciętnego wynagrodzenia $w$ gospodarce narodowej $w 2018 \mathrm{r}$. (M.P. 2019, poz. 154). Pozyskano z http://prawo.sejm.gov.pl/isap.nsf/DocDetails. xsp?id=WMP20190000154 (dostęp: 3.12.2019).

Ministerstwo Rodziny, Pracy i Polityki Społecznej (2018). Obwieszczenie Ministra Rodziny, Pracy i Polityki Społecznej z dnia 23 listopada 2018 r. w sprawie kwoty ograniczenia rocznej podstawy wymiaru składek na ubezpieczenia emerytalne i rentowe $w$ roku 2019 oraz przyjętej do jej ustalenia kwoty prognozowanego przeciętnego wynagrodzenia (M.P. 2018, poz. 1185). Pozyskano z http://prawo.sejm.gov.pl/isap. nsf/DocDetails.xsp?id=WMP20180001185 (dostęp: 3.12.2019).

Ministerstwo Rodziny, Pracy i Polityki Społecznej (2019). Obwieszczenie Ministra Rodziny, Pracy i Polityki Społecznej z dnia 28 listopada 2019 r. w sprawie kwoty ograniczenia rocznej podstawy wymiaru składek na ubezpieczenia emerytalne i rentowe w roku 2020 oraz przyjętej do jej ustalenia kwoty prognozowanego przeciętnego wynagrodzenia (M.P. 2019, poz. 1147). Pozyskano z http://prawo.sejm.gov.pl/isap. nsf/DocDetails.xsp?id=WMP20190001147 (dostęp: 3.12.2019). 


\section{Literatura}

Furmańska-Maruszak, A. (2008). Koszty pracy a zatrudnienie - wspótczesne koncepcje a rzeczywistość. Toruń, Polska: Wydawnictwo Dom Organizatora.

Góra, M., Radziwiłł, A., Sowa, A., \& Walewski, M. (2006). Tax Wedge and Skills: Case of Poland in International Perspective. No. 64. Warszawa, Polska: CASE Reports.

GUS (2017). Koszty pracy w gospodarce narodowej w 2016 r. Pozyskano z https://stat. gov.pl/obszary-tematyczne/rynek-pracy/pracujacy-zatrudnieni-wynagrodzenia-koszty-pracy/koszty-pracy-w-gospodarce-narodowej-w-2016-r-,8,5.html (dostęp: 3.12.2019).

Kasperowicz-Stępień, A. (2007). Klin podatkowy jako jedna z barier rozwoju rynku pracy w Polsce. Zeszyty Naukowe Uniwersytetu Ekonomicznego w Krakowie, 754, 73-85.

Krajewska, A. (2016). Opodatkowanie pracy w OECD. Analiza porównawcza i wnioski dla Polski. Annales UMCS. Sectio H Oeconomia, 50(1), 669-680.

Krajewska, A. (2019). Opodatkowanie konsumpcji, pracy i kapitału w krajach Unii Europejskiej. Gospodarka Narodowa, 2(298), 41-63.

Mazurek-Chwiejczak, M. (2016a). Opodatkowanie dochodów z pracy w państwach OECD - studium porównawcze. Przedsiębiorstwo i Region, 8, 166-185.

Mazurek-Chwiejczak, M. (2016b). Trends in Personal Income Tax Progression in OECD Countries in the Context of Income Redistribution. Acta Universitatis Lodziensis. Folia Oeconomica, 4(324), 181-193.

OECD (2010). Tax Policy Reform and Economic Growth. No. 20. Paryż, Francja: OECD Publishing - OECD Tax Policy Study.

OECD (2012). Income Inequality and Growth: The Role of Taxes and Transfers. OECD Economic Department Policy Notes, 9, 1-14.

OECD (2019). Taxing Wages 2019. Paryż, Francja: OECD Publishing.

OECD (n.d.). Taxing Wages - Comparative Tables (database). Pozyskano z https://stats. oecd.org/Index.aspx?DataSetCode=AWCOMP (dostęp: 3.12.2019).

Biuro Analiz Sądowych (2007). Klin podatkowy a bezrobocie. Pozyskano z http://orka. sejm.gov.pl (dostęp: 3.12.2019).

Biuro Analiz Sądowych (2008). Opodatkowanie wynagrodzeń za pracę (składki i PIT) w państwach Unii Europejskiej. Pozyskano z http://orka.sejm.gov.pl (dostęp: 3.12.2019).

Rosiński, R. (2013). Zmiany płacowego klina podatkowego w wybranych krajach Unii Europejskiej w obliczu kryzysu finansów publicznych. Zarządzanie i Finanse, 2(3), 361-373.

Rosiński, R. (2017). Struktura kosztów pracy w wybranych państwach Unii Europejskiej. Finanse, Rynki Finansowe, Ubezpieczenia, 3(87), 151-160. 
Russel, P. (2008). Kierunki zmian w opodatkowaniu dochodów osobistych w państwach UE. W: M. Korolewska (red.), Tendencje w opodatkowaniu dochodów osób fizycznych w państwach UE (ss. 71-92). Warszawa, Polska: Studia BAS. Biuro Analiz Sejmowych Kancelarii Sejmu.

Rada Ministrów (2019). Sprawozdanie z wykonania budżetu państwa za okres od 1 stycznia do 31 grudnia 2018 r. Omówienie. Pozyskano z https://www.gov.pl/web/finanse/ sprawozdanie-roczne-za-2018 (dostęp: 3.12.2009).

Wojciuk, M., \& Dziemianowicz, R. (2017). Ocena progresywności klina podatkowego w Polsce i w wybranych krajach Unii Europejskiej. Prace Naukowe Uniwersytetu Ekonomicznego we Wrocławiu, 475, 390-404.

Wojciuk, M. (2018). Labour Taxation versus Employment Models in Poland. Optimum. Economic Studies, 2(92), 138-152.

ZUS (n.d.). Archiwum stóp procentowych ZUS. Pozyskano z https://www.pit.pl/zus-stopy-procentowe/archiwum-stop-procentowych-zus-923047 (dostęp:3.12.2019).

\section{Streszczenie}

W ostatnich latach do konstrukcji podatku dochodowego od osób fizycznych wprowadzane są zmiany mające na celu obniżenie wysokości zobowiązania podatkowego, w szczególności dla podatników osiągających relatywnie niskie dochody. Od 1 stycznia 2017 r. obowiązują nowe zasady ustalania kwoty wolnej od podatku, z dniem 1 października 2019 r. ponad dwukrotnie zwiększono wysokość kosztów uzyskania przychodów, a także zredukowano o 1 pkt. proc. stawkę obowiązującą w najniższym przedziale skali podatkowej.

Celem artykułu jest zbadanie, w jakim stopniu przyjęcie wskazanych regulacji wpłynęło na zmianę poziomu klina podatkowego w Polsce oraz na zwiększenie stopnia jego progresywności. W realizacji tak postawionego celu posłużono się metodami analizy opisowej, analizy porównawczej, a także prostymi metodami statystycznymi, w tym miarami średnimi i pozycyjnymi. Wysokość pozapłacowych kosztów pracy w Polsce odniesiono na podstawie danych statystycznych OECD do rozwiązań obowiązujących w innych krajach. Dokonano także dekompozycji klina podatkowego i określono stopień jego progresywności. W dalszej części, wykorzystując wyniki własnych obliczeń, określono wysokość klina podatkowego w Polsce w latach 2019-2020 dla różnych poziomów dochodu.

Przeprowadzone badania pozwoliły na sfomułowanie wniosku, iż implementacja nowych przepisów nie wpłynęła zasadniczo na poziom pozapłacowych kosztów pracy w Polsce, których wysokość oscyluje w granicach średniej OECD. Nowe regulacje nie przyczyniły się także do zwiększenia stopnia progresywności polskiego klina płacowego, który w dalszym ciągu jest niewielki. Tym samym należy stwierdzić, że klinowi podatkowemu w Polsce nie można przypisać funkcji redystrybucyjnej. 
SŁowA KLUCzOWE: klin podatkowy, opodatkowanie pracy, podatek dochodowy od osób fizycznych, składki na ubezpieczenie społeczne, progresywność

\section{Summary}

The construction of Personal Income Tax in Poland has been modified in recent years. Since January $1^{\text {st }}$, 2017, the sum of tax-free allowance was calculated on the basis of new rules. Since October $1^{\text {st }}, 2019$, the level of the tax rate in the first tax bracket was reduced by 1 p.p. and the level of tax-deductible costs was more than doubled.

The aim of the article is to examine whether the implementation of these new regulations has significantly modified the height of the tax wedge and the level of its progressivity. The techniques of description analysis, comparative analysis and simple statistical methods (average and positional indicators) have been used to achieve this aim. The level of the tax wedge in Poland, as well as its structure and level of its progressivity has been compared to other well-developed countries. The results of own calculation concerning the level of tax wedge for different taxpayers for the years 2018-2020 has been also presented.

The conclusions are the implementation of new regulation has not significantly affected the level of tax wedge in Poland, which is still close to the OECD average. What is more, it has not also increased to the level of tax wedge progressivity, which is one of the lowest in OECD and can cause some tensions.

KeYwords: tax wedge, labour taxation, Personal Income Tax, Social Security Contributions, progressivity 